\title{
THE CORRELATION BETWEEN STUDENTS' VOCABULARY MASTERY AND THEIR TRANSLATION ABILITY AT THE FIRST SEMESTER OF THE ELEVENTH GRADE OF MAN 2 BANDAR LAMPUNG IN THE ACADEMIC YEAR OF 2017/2018
}

\author{
Iwan Kurniawan ${ }^{1 *}$, Anggi Yogi Saputri, Rahmiati Isnaini \\ Universitas Islam Negeri Raden Intan Lampung \\ iwankurniawan@ radenintan.ac.id
}

\begin{abstract}
In this research, the researcher focused on the correlation between students' vocabulary mastery and their translation ability. The research objective was to know whether there was a correlation between students' vocabulary mastery and their translation ability at the first semester of the eleventh grade of MAN 2 Bandar Lampung in the academic year of 2017/2018. There were two variables in this research, the independent variable, vocabulary mastery $(X)$ and dependent variable, Translation ability $(Y)$. This is correlational research, and it is used to know the correlation between vocabulary mastery and translation ability. In taking the sample of the research, the cluster random sampling was applied. The research population was taken from the students of the eleventh grade of MAN 2 Bandar Lampung in 2017/2018. The sample of the research was taken 39 students from 197 populations. In collecting the research data, the researcher used objective tests that consisted of 20 items and one text for the translation test. In this research, SPSS was used to compute Pearson Product Moment's formula. After doing the hypothetical testing, the result demonstrated a positive correlation between students' vocabulary mastery and their translation ability. Based on the data analysis computed by SPSS, it was obtained that Sig $\left(P_{\text {Value }}\right)=0.000$ and $\alpha=0.05$. $H_{a}$ was accepted and $H_{o}$ was rejected because Sig $\left(P_{\text {Value }}\right)=0.000<\alpha=0.05$. Based on this research, it was suggested that to have a good ability in translating; the students should have a good mastery of vocabulary.
\end{abstract}

Key words: Correlation Study, Translation and Vocabulary

\section{A. BACKGROUND OF THE PROBLEM}

Language is considered as a tool of communication and language cannot be separated from community, because the people can communicate with other people by using language. However, they cannot understand what other people say if they do not know the language that they use. Then, Patel states that language is a system 
of communications through which consist of a set of sounds and written symbols which are used by the people of a particular country for talking of writing. It means that the language is very important in human life. Without language they cannot deliver their feelings, opinions, and thoughts to each other. It is difficult to do all activities without language.

Nowadays, English plays an important role in the world. As an international language, it is used to disseminate information and news around the world. For our country, English helps the Indonesian people be cognizant of the development and their knowledge.

English also becomes very important for people to exchange meaning and represent their feeling and idea. Learning a foreign language is different from learning one's mother tongue. The students will meet a lot of difficulties in learning a foreign language (the target language/TL) because each language has its own vocabulary items and unfamiliar ways of arranging the words into sentences.

Based on this problem, translation is considered a very important thing to connect the two different languages by contributing source language (SL) into target language. Catford defines that translation is the replacement of textual material in one language (source language) by equivalent textual material in another language(target language). It means that translation is an activity of rewriting a text from its source language into the target language without modifying or changing its meaning in order to make the information in the source language become acceptable and understandable for students.

In teaching learning English as foreign language, the students have to be able to understand words. If they do not understand and do not know the meaning of English vocabulary, they will get difficulties in learning foreign language especially English. In this case, translation is needed to understand what people express and say in their languages, write in their letters, and communicate with their friends.

Translation is not an easy job that can be done by anyone without knowing the procedures, methods and techniques of translating. Then, Ordudari in Translation 
Journal states that the difference between the source language and the target language and the variations of their culture make the process of translating a real challenge. Among the problematic factors involved in translation are form, meaning, style, proverbs, idioms, grammar mastery and vocabulary mastery. It means that in translating, the difference culture is the challenge for translator. In translation there are some factors such as, form, meaning, style, proverb, idioms, grammar mastery and vocabulary mastery.

Something influential of translation is the vocabulary mastery. Vocabulary plays an important role in learning English. Like other languages, in learning English, learners have to be able to understand words. In fact, it happens that students want to express something in English but they do not know how to express the word appropriately because of the lack of vocabulary. Therefore, Snow et.al cited in Tankersly states that vocabulary is the meaning and pronounciation of words that we use in communication. It means that vocabulary is the vital part of language that students used in communication. Without vocabulary it is impossible for them to learn language. By mastery vocabulary, they will be easy to communicate to each other.

Vocabulary development is an important aspect of language development. In dealing with vocabulary, one should consider three important aspects of vocabulary such as how word form, how word meaning, and also how word usage. Word formation means to know how words are spoken, written, and how they can change their form. Then meaning encompasses the way that form and meaning work together in other words, the concept and what items it refers to, and the association that come to mind when people think about a specific word or expression. These are to realize about vocabulary items that they frequently have more than one meaning. Sometimes, word has meanings in relation to other words. The meaning of language depends on where it occurs within a large stretch of discourse. Here, the grammatical function use of the words or phrase, the collocation that normally occur with a language use, and any constraints used (in term of frequency, level, so forth). 
Regarding the explanation, the researcher summarizes that in general, vocabulary can be classified into some part covering all words in language. After knowing some points of vocabulary, it is clear that the students should have a great skill on vocabulary. Not only mastery in a rich vocabulary but also understand about using of vocabulary adequately.

In preliminary research at MAN 2 Bandar Lampung, the researcher asked Mrs. Wahyu Fardushila, S.Pd as the English teacher about the students' capability in English, especially about their vocabulary mastery and their translation ability. She said that that students got difficulty in translating because they lack of vocabulary. In doing preliminary research, the researcher got the data of vocabulary mastery of the eleventh grade of MAN 2 Bandar Lampung. It can be seen from table of the students' score given by the teacher below:

Table 1. The Students' Vocabulary Score of the Eleventh Grade of MAN 2 Bandar Lampung in the Academic Year of 2017/2018

\begin{tabular}{|c|c|c|c|c|c|c|c|c|}
\hline \multirow[b]{2}{*}{ No } & \multirow[b]{2}{*}{ Score } & \multicolumn{5}{|c|}{ Class } & \multirow[b]{2}{*}{ Total } & \multirow[b]{2}{*}{ Percentage } \\
\hline & & $\begin{array}{c}\text { XI } \\
\text { MIA1 }\end{array}$ & $\begin{array}{c}\text { XI } \\
\text { MIA2 }\end{array}$ & $\begin{array}{c}\text { XI } \\
\text { MIA3 }\end{array}$ & $\begin{array}{c}\text { XI } \\
\text { MIA4 }\end{array}$ & $\begin{array}{c}\text { XI } \\
\text { MIA5 }\end{array}$ & & \\
\hline 1 & $<73$ & 22 & 25 & 21 & 27 & 29 & 124 & $62.94 \%$ \\
\hline 2 & $\geq 73$ & 18 & 14 & 19 & 12 & 10 & 73 & $37.05 \%$ \\
\hline Total & & 40 & 39 & 40 & 39 & 39 & 197 & $100 \%$ \\
\hline
\end{tabular}

Source : Document of English Vocabulary Score of the Eleventh Grade of MAN 2 Bandar Lampung in the Academic Year of 2017/2018.

From the table above, 124 students who get score $<73$, and 73 students get the score $\geq 73$. It is obvious that more than $50 \%$ of students need to increase their vocabulary mastery because at MAN 2 Bandar Lampung, the criteria score of minimum mastery $(\mathrm{KKM})$ is 73 .

The researcher also did preliminary research to get students' translation ability score. Students' translation ability score is as follows: 
Table 2. The Translation Score of the Eleventh Grade of MAN 2 Bandar Lampung in the Academic Year of 2017/2018.

\begin{tabular}{|c|c|c|c|c|c|c|c|c|}
\hline \multirow{2}{*}{ No } & \multirow{3}{*}{} & \multicolumn{5}{|c|}{ Class } & \multirow{2}{*}{} & \multirow{2}{*}{ Percentage } \\
\cline { 3 - 8 } & Score & XI & XI & XI & XI & XI & Total & PIA \\
& & MIA2 & MIA3 & MIA4 & MIA5 & & \\
\hline 1 & $<73$ & 21 & 24 & 22 & 26 & 30 & 123 & $62.43 \%$ \\
\hline 2 & $\geq 73$ & 19 & 15 & 18 & 13 & 9 & 74 & $37.56 \%$ \\
\hline Total & & 40 & 39 & 40 & 39 & 39 & 197 & $100 \%$ \\
\hline
\end{tabular}

Source : Document of translation Ability Score of the Eleventh Grade of MAN 2 Bandar Lampung in 2017/2018 Academic Year

From the table above, 123 students who get score $<73$, and 74 students get the score $\geq 73$. It is obvious that more than $50 \%$ of students need to increase their translation ability because at MAN 2 Bandar Lampung, the criteria score of minimum mastery (KKM) for English subject is 73 .

There were two researchers related to this research that have been conducted. The first was research conducted by Kurniati who studied (the correlation between part of speech mastery and translation ability at the first semester of the eleventh grade of MA MA'ARIF bumi Restu Palas Lampung Selatan the academic year of 2013/2014). It was found that there is positive correlation between students' part of speech mastery and translation ability because by seeing the result of the data calculation in which null hypothesis (Ho) is rejected and alternative hypothesis (Ha) is consequently accepted. So she concluded that good part of speech mastery enables good translation ability. It is supported by the scores the students achieved, in which they received higher scores after she gave the test. So the researcher can conclude that if the students have good part of speech mastery enables have good ability in translating.

Another research was conducted by Wahyuningsih in her thesis entitled "The Correlation between Vocabulary Mastery and Reading Comprehension at Eight Grade Students of SMP PGRI 1 Kediri in Academic year 2014/2015. There were 
two things which were discussed in this study, vocabulary mastery and reading comprehension. The objective of this study was to show the correlation between vocabulary mastery and reading comprehension. Increasing vocabulary skill is one of the most important things to reach the students goal in comprehension skills. The research findings showed that the vocabulary mastery affected the students' performance in reading comprehension. As the influence is positive one, it supported the basic assumption that the students who got high score in vocabulary test, they would get the score in comprehension as well. It means that the more students have many stocks of words, the better they perform in comprehension.

Dealing with discussion above, it is predicted that the students who are good in vocabulary will be able to translate well. This research is done for the intention of exploring how significant the vocabulary mastery and translation. Therefore the researcher conducted a research entitled: "The Correlation between Students' Vocabulary Mastery and Their Translation Ability at the First Semester of Eleventh Grade of MAN 2 Bandar Lampung in the Academic Year of 2017/2018.”

\section{B. Formulation of the Problem}

Referring to the problem above, the researcher formulated the main problem as follows; is there any correlation of students' vocabulary mastery and their translation ability?

\section{Significance of the Research}

1. Theoretically

This research hopefully gave information about vocabulary mastery and translation ability. This research also enriched the previous studies about the correlation between vocabulary mastery and translation ability.

2. Practically

The practical as significance that the researcher expected from this research are as follows:

a. For students: the finding of the research will motivate them to practice more than they did before and encourage them to learn English by improving their 
vocabulary mastery through some fun ways. In addition, by improving their vocabulary mastery, they will be able to increase their translation ability.

b. For teachers: the result of the research will be useful as a reflection in order to increase and develop their method in teaching students about vocabulary relating to its importance in their ability in translation.

c. For other researchers: the finding of the research hopefully can be useful as the source of their reference and it is also useful to inform the readers about the correlation between students' mastery of vocabulary and their translation ability of the eleventh grades of MAN 2 Bandar Lampung.

\section{B. VOCABULARY MASTERY AND TRANSLATION ABILITY}

\section{Vocabulary Mastery}

Vocabulary is the first basic important aspect for learning English by learner, by mastering vocabulary they are able to communicate both orally and written well. Also by having a lot of vocabularies, the students are hoped to master four skills in English such as: listening, speaking, reading and writing.

Meanwhile, Hornby states that mastery is great knowledge about or understanding of a particular thing. From that definition, it comes to the conclusion that mastery means the competency to understand and apply something learnt.

Seeing the explanation, the researcher concludes that vocabulary mastery is the ability to know the meanings of certain vocabulary items and their usage in certain context to express ideas, opinion, and feelings in communication. In other word, vocabulary mastery is people's ability to use or to understand words of language that they have learned in certain situations which they really have experienced in their lives.

\section{Translation Ability}

Translation typically has been used to transfer written or spoken of source language texts to equivalent written or spoken TL texts. In other word, translation is a change of form from one language into another one both oral and written language. 
Meanwhile, Hornby states that ability is able to do. It means that ability is the capacity of someone to carry out a particular thing.

The ability in translating a language into another language is indicated by the quality of translation result. Translation ability can be achieved if translator (students') is able to generate target text and can adapt to the reader. It requires a good translator. Translator is someone who has the comprehensive knowledge of both source and target language. According to Newmark "a translator requires knowledge of literary and non-literary textual criticism, since he/she has to the quality of a text before he decides how to interpret and then translate it". It means that translation is the ability which of course requires certain qualification of translator. A translator has to understand the written message in the foreign language before transferring into target language.

Regarding the explanation, good translator is one of top key in translation activity so that the successful of this activity depend on the students' knowledge. They must give more attention to the reader in target language. A translator must be also being accountable for his or her translation works by considering compatibility between source text and target text. That's way, he or she can create good translation.

In translating activity, it possible that someone facing some problems to translate from source language (SL) into a target language (TL). Failure to clear this activity may be due to the students' poor or insufficient knowledge of vocabulary or lack of information. However, translating is an interesting activity because we play with some words and sentences especially in translating English into Indonesian. This activity challenged to mix and match the words that the translator has acquired to the new words in English which has different structure

\section{RESEARCH DESIGN}

In this research, the researcher used quantitative method and used correlational research as a research design. According to Lodico et.al "correlational research is a quantitative method designed to show the relationships between two or more variables". It means that correlational study is the method to determine whether one 
variable have relationship with another variable. Therefore, Fraenkel et.al states that the purpose of correlational research is to clarify our understanding of important phenomena by identifying relationships among variables.

In this research, the researcher wants to know whether the correlation between those two variables existed or not. Thus, the most appropriate research design used to answer whether or not students' vocabulary mastery correlated to the translation ability of eleventh-grade students at MAN 2 Bandar Lampung in the academic year of 2017/2018 is correlational design.

\section{a. Population, Sample, and the Sampling Technique of the Research \\ 1. Population}

Population, sample, and sampling were very essential in this research because without all of them, this research could not be conducted. Sugiyono defines population is generalization area that consist of object or subject which having certain qualities and characteristics determined to learn then concluded by researcher. It means that population is the larger group of individual has one more characteristics in common that are of interest to the researcher. In other word, population is a number of groups which the researcher would like to make the results of the research to be reported.

The population of the research was the students at the first semester of the eleventh grade of MAN 2 Bandar Lampung in the academic year of 2017/2018. The total population in this research is 197 students.

\section{Sample}

Sample is a small portion of population. According to Lodico et al "A sample is a smaller group selected from a larger population (in this case, a realistic population) that is representative of the larger population". It means that sample is a representative part of population that was took to represent the research. The sample of this research was class XI MIA 2 at MAN 2 Bandar Lampung. 


\section{The Sampling Technique}

Sampling is the process that used to select the sample. As Fraenkel et al defined that sampling was the selection of the sample of individuals who will participate (be observed or questioned). It had purpose to gain information about a population. Here, sampling is very important way to obtain a group of a subject who will be representative of the larger population or will provide specific information needed.

In this research, the researcher used cluster random sampling technique because the population is in groups and homogenous.

In MAN 2 Bandar Lampung the number of the eleventh grade are 5 classes namely: XI MIA 1, XI MIA 2, XI MIA 3, XI MIA 4 and XI MIA 5.

Here are the steps that followed by researcher to determining the sample:

1. First, the researcher provided 5 pieces of paper consisting of five classes, XI MIA 1, XI MIA 2, XI MIA 3, XI MIA 4 and XI MIA 5.

2. Next, the researcher rolled those pieces of paper and put them into a box.

3. Then, the researcher shook the box until the one rolled paper came out of it. Then, this rolled paper took as the sample. It was gotten XI MIA 2 as a sample of this research.

\section{b. The Data Collecting Technique}

Collecting data is the most important step in conducting the research. In collecting data in this research, the researcher used a test. According to Donal ary, test is a set of stimuli presented to an individual in order to elicit responses on the basis of which a numerical score can be assigned. It means that a test is a device that contains a series of the task to do or questions to be answered by someone to measure the one aspect specific behavior. Thus, the function of the test is as a tool to measure.

Before conducting the real test, the researcher conducted a try out test to get the validity and reliability of each test item. In this research, the researcher gave two kinds of tests, namely vocabulary and translation to get the data or information. 


\section{c. The Instruments}

Sugiyono states that research instrument is a tool used by researcher to measure the nature or social phenomena being observed. Here, it had purpose as a tool to get the data. It is used to measure the students' ability and to get the data to prove the theory. In this research, the researcher used a test as instrument namely vocabulary test and translation test. Those tests are:

\section{Vocabulary Test}

For the vocabulary test, the researcher used the multiple-choice with four options ; $\mathrm{a}, \mathrm{b}, \mathrm{c}$ and $\mathrm{d}$. Thornbury states that Multiple-choice tests are the popular way of testing in that they are easy to score and they are easy to design. Before the researcher gave the try out test to the students, the instrument consisted of 40 items and after try out test the instrument consisted of 20 items.

\section{Translation Test}

The translating test gave to measure the students' translating ability. In translating the students should translate text from Indonesian into English based on the theme given. In this case, the students translate a text especially report text during 90 minutes for time allocation.

\section{d. The Scoring System}

\section{a. Vocabulary mastery test}

In scoring vocabulary test, The ideal highest score is 100 , the answer is score 1 if it is correct and score 0 if it is incorrect, by using the following formula:

$$
\mathrm{S}=\frac{r}{N} X 100
$$

\section{Notes :}

$s=$ The score of test

$\mathrm{r}=$ Total of test which is correct.

$n=$ The total item.

\section{b. Translating test}


Then, in scoring the students' translation ability, criteria of rating scale adapted from Machali used to calculate translating test. The translation score can be seen on the table below:

Table 8. Scoring System by Rochayah Machali

\begin{tabular}{|c|c|c|}
\hline Category & Score & Indicator \\
\hline The translation is almost perfect & $\begin{array}{l}86-90 \\
(\mathrm{~A})\end{array}$ & $\begin{array}{l}\text { The translation is almost equal to original } \\
\text { text. There are no mistake in grammar, } \\
\text { spelling and using vocabulary. }\end{array}$ \\
\hline The translation is very good & $\begin{array}{c}76-85 \\
\text { (B) }\end{array}$ & $\begin{array}{l}\text { There are no mistake in using vocabulary, } \\
\text { there are any grammar and spelling } \\
\text { mistake but not many. }\end{array}$ \\
\hline The translation is good & $\begin{array}{l}65-75 \\
(\mathrm{C})\end{array}$ & $\begin{array}{l}\text { There are grammar and idiom mistakes } \\
\text { but not more than } 15 \% \text { from all texts. } \\
\text { There are any mistakes in spelling. }\end{array}$ \\
\hline The translation is enough & $\begin{array}{l}46-60 \\
\text { (D) }\end{array}$ & $\begin{array}{l}\text { There are grammar and idiom mistakes } \\
\text { but not more than } 25 \% \text { from all texts. } \\
\text { There are any mistakes in uncommon } \\
\text { vocabulary. }\end{array}$ \\
\hline The translation is worse & $\begin{array}{c}20-45 \\
(\mathrm{E})\end{array}$ & $\begin{array}{l}\text { There are grammar and idiom mistakes } \\
\text { more than } 25 \% \text { from all texts. }\end{array}$ \\
\hline
\end{tabular}

Source: Scoring System by Rochayah Machali.

\section{e. The Data Analysis}

To analyze the data, the researcher used parametric statistics. In parametric statistics, there

Linearity test is used to know the size of the linear relationship between two variables $\mathrm{x}$ and $\mathrm{y}$. before analyzing the data by using Pearson's product moment formula to know correlation level. 
English Education: Jurnal Tadris Bahasa Inggris

\section{RESEARCH RESULT AND DISCUSSION}

\section{Result of the Vocabulary Mastery Test}

The test was conducted in order to know the students' vocabulary mastery. The test was administered in MAN 2 Bandar Lampung onOctober $31^{\text {th }}, 2017$. The minimum score was 40 and the maximum score was 95 . There were 1 student who got the score 40, 1 student who got the score 90, and 18 students got score lower than 75 . The mean of the vocabulary mastery test is 68.59 .

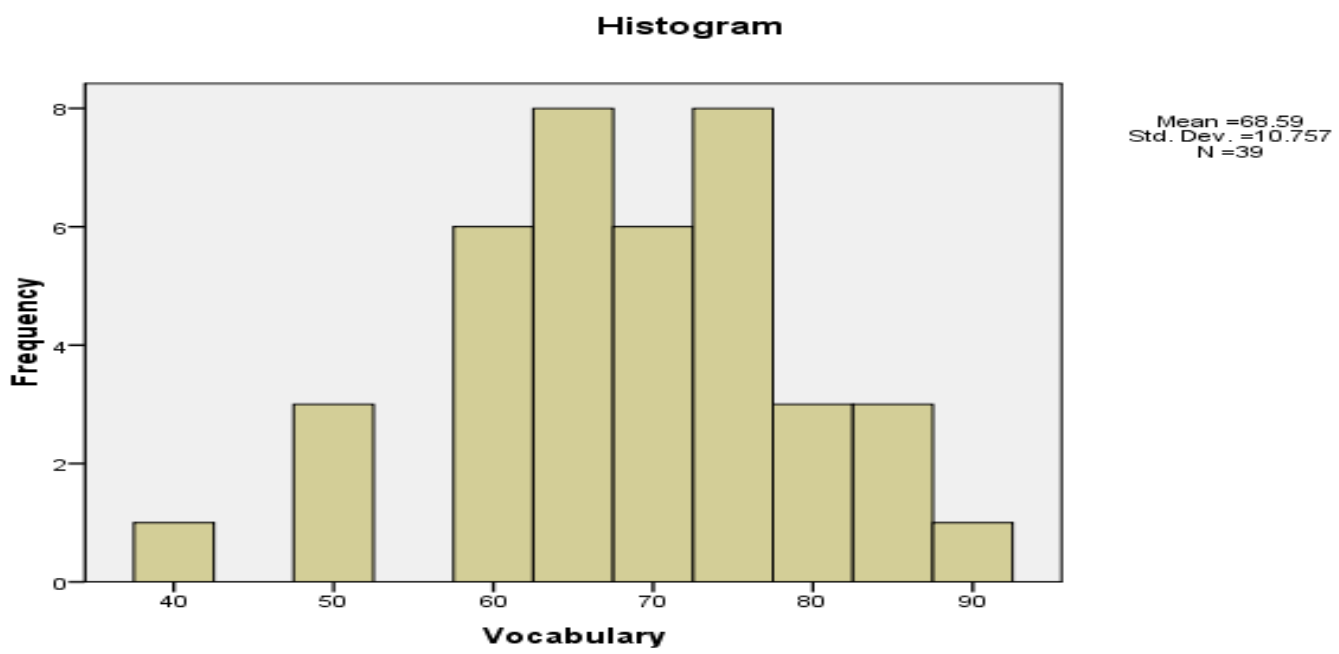

Figure 2. The Result of vocabulary Mastery Test

Based on the figure 2, it can be seen that there were 23 students who get under average scores and 14 students get a good scores over average score 73 (Standard Minimum of Criteria).

\section{a. Result of the Translation Test}

The test was conducted in order to know the students' translation ability. The test was administered in MAN 2 Bandar Lampung on November $4^{\text {th }}, 2017$. The minimum score was 46 and the maximum score was 86 . There were 5 students who got the score 46, 1 student who got the score 86 , and 29 students who got the score lower than 75 . The mean of the translation ability test is 65.38 . 
English Education: Jurnal Tadris Bahasa Inggris

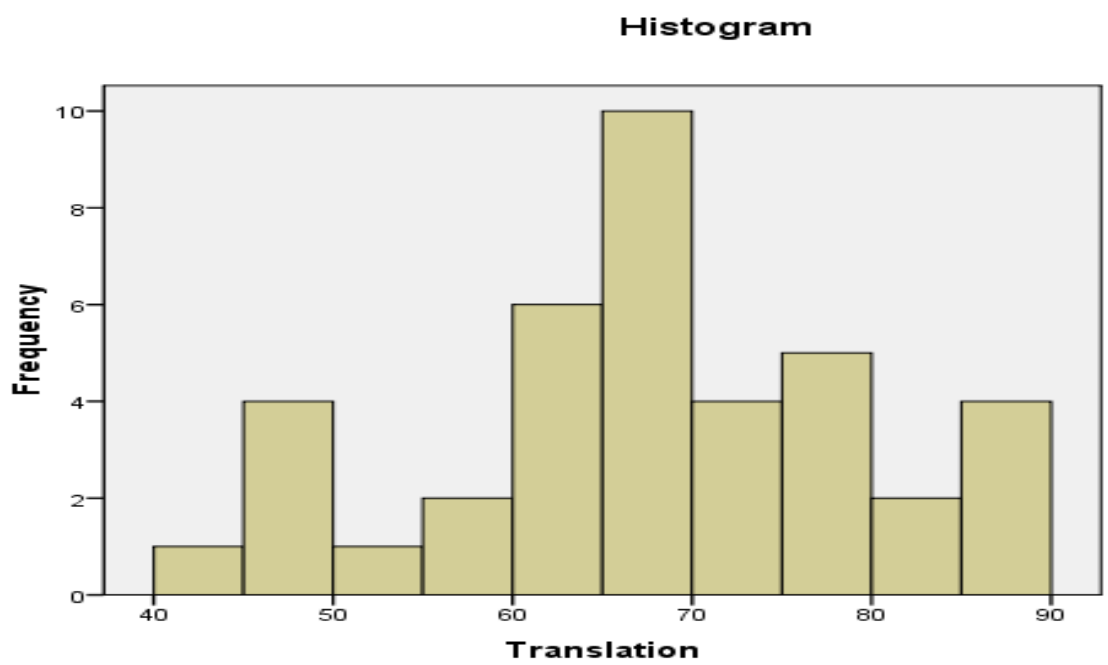

$\begin{aligned} \text { Mean } & =65.38 \\ \text { Std. Deev } & =11.842 \\ N & =39\end{aligned}$

Figure 3. The Result of Translation Ability Test

Based on the figure 1, it can be seen that there were 28 students who got score under average scores and 11 students who got the score over average score (Standard Minimum of Criteria).

\section{A. Result of the Data Analysis}

\section{Fulfillment of Assumptions}

Before knowing the result of the data analysis by using Pearson Product Moment's formula, there were two assumptions that must be done and found out. They were normality test and linearity test.

\section{a. Result of Normality Test}

The normality test is used to measure whether the data in the vocabulary mastery and translation ability were normally distributed or not. In this research, statistical computation by using SPSS (Statistical Package for the Social Science) was used for normality of the test. The test normality employed were Kolmogorov - Smirnov and Shapiro -Wilk. $\mathrm{H}_{\mathrm{o}}$ is accepted if $\mathrm{Sig}\left(\mathrm{P}_{\text {Value }}\right)>\alpha=0.05$.

The hypotheses for the normality test were formulated as follows:

$\mathrm{H}_{\mathrm{o}} \quad$ : The data are normally distributed.

$\mathrm{H}_{\mathrm{a}} \quad$ : The data are not normally distributed.

While the criteria acceptance and rejection of normality test are: 
$\mathrm{H}_{\mathrm{o}}$ is accepted if $\operatorname{sig}>\alpha=0.05$

$\mathrm{H}_{\mathrm{a}}$ is accepted if $\operatorname{sig}<\alpha=0.05$

Table 11. Result of Normality Test

\begin{tabular}{|l|r|r|r|r|r|r|}
\hline & \multicolumn{3}{|c|}{ Kolmogorov-Smirnov $^{\mathrm{a}}$} & \multicolumn{3}{c|}{ Shapiro-Wilk $^{*}$} \\
\cline { 2 - 7 } & Statistic & \multicolumn{1}{c|}{ Df } & \multicolumn{1}{c|}{ Sig. } & Statistic & \multicolumn{1}{c|}{ df } & \multicolumn{1}{c|}{ Sig. } \\
\hline Vocabulary & .113 & 39 & $.200 *$ & .965 & 39 & .258 \\
Translation & .128 & 39 & .105 & .957 & 39 & .142 \\
\hline
\end{tabular}

a. Lilliefors Significance Correction

*. This is a lower bound of the true significance.

Based on the table above, it can be seen that $\operatorname{Sig}\left(\mathrm{P}_{\text {value }}\right)$ for vocabulary mastery was 0.258 and $\mathrm{Sig}\left(\mathrm{P}_{\text {value }}\right)$ for translation ability was 0.142 . Because $\mathrm{Sig}\left(\mathrm{P}_{\text {value }}\right)$ of vocabulary mastery and translation ability higher than 0.05 it means $\mathrm{H}_{\mathrm{o}}$ was accepted. The conclusion was that the data in vocabulary mastery and translation ability had normal distribution.

\section{b. Result of Linearity Test}

The test was intended to test whether the data obtained were linear or not because this was one of requirements to be able to use the Pearson product moment formula. The researcher used SPSS Statistic 16.0 and the result was as follow: 
English Education: Jurnal Tadris Bahasa Inggris

Table 12. Result of Linearity Test

\begin{tabular}{|c|c|c|c|c|c|c|c|}
\hline & & & $\begin{array}{l}\text { Sum of } \\
\text { Squares }\end{array}$ & $\mathrm{df}$ & $\begin{array}{l}\text { Mean } \\
\text { Square }\end{array}$ & $\mathrm{F}$ & Sig. \\
\hline $\begin{array}{l}\text { Translation } \\
* \\
\text { Vocabulary }\end{array}$ & $\begin{array}{l}\text { Between } \\
\text { Groups } \\
\text { Within C } \\
\text { Total }\end{array}$ & $\begin{array}{l}\text { (Combined) } \\
\text { Linearity } \\
\text { Deviation } \\
\text { from } \\
\text { Linearity } \\
\text { ups }\end{array}$ & $\begin{array}{r}2432.689 \\
1574.320 \\
858.369 \\
2896.542 \\
5329.231\end{array}$ & $\begin{array}{l}30 \\
38\end{array}$ & $\begin{array}{r}304.086 \\
1574.320 \\
122.624 \\
96.551\end{array}$ & $\begin{array}{r}3.149 \\
16.306 \\
1.270\end{array}$ & $\begin{array}{l}.010 \\
.000 \\
.298\end{array}$ \\
\hline
\end{tabular}

Based on table, it can be seen that $\operatorname{Sig}\left(\mathrm{P}_{\text {value }}\right)$ was 0.298 and $\alpha=0.05$. It means that $\operatorname{Sig}\left(\mathrm{P}_{\text {value }}\right)>\alpha$. The conclusion was that the data were linear.

\section{Result of Hypothetical Test}

The hypothesis is very important to find out whether or not the alternative $\left(\mathrm{H}_{\mathrm{a}}\right)$ or null hypothesis $\left(\mathrm{H}_{\mathrm{o}}\right)$ is accepted in this research. The Pearson Product Moment's formula by using SPSS (Statistical Package for the Social Science) was computed for testing hypothesis.

The hypothesis of this research are as follows:

$\mathrm{H}_{\alpha}$ : There was correlation between students' vocabulary mastery and their translation ability at the first semester of eleventh grade of MAN 2 Bandar Lampung in the academic year of 2017/2018.

$\mathrm{H}_{\mathrm{o}}$ :There was no correlation between students' vocabulary mastery and their translation ability at the first semester of eleventh grade of MAN 2 Bandar Lampung in the academic year of 2017/2018.

While the criteria acceptance or rejection of hypothesis testare as follows: 
$\mathrm{H}_{\mathrm{a}}$ was accepted if Sig. $<\alpha=0.05$

$\mathrm{H}_{\mathrm{ow}}$ as accepted if Sig. $>\alpha=0.05$

Table 13. Result of Hypothetical Test

\begin{tabular}{|c|c|c|c|}
\hline \multicolumn{4}{|c|}{ Correlations } \\
\hline & & Vocabulary & Translation \\
\hline \multirow[t]{3}{*}{ Vocabulary } & Pearson Correlation & 1 & $.544^{* * *}$ \\
\hline & Sig. (2-tailed) & & .000 \\
\hline & $\mathrm{N}$ & 39 & 39 \\
\hline \multirow[t]{3}{*}{ Translation } & Pearson Correlation & $.544^{* *}$ & 1 \\
\hline & Sig. (2-tailed) & .000 & \\
\hline & $\mathrm{N}$ & 39 & 39 \\
\hline
\end{tabular}

**. Correlation is significant at the 0.01 level (2-tailed).

Based on the results obtained in the Pearson Product Moments' formula, it was clear that the value of significant generated Sig. $\left(\mathrm{P}_{\text {Value }}\right)=0.000<\alpha=0.05$. So $\mathrm{H}_{\mathrm{o}}$ was rejected and $\mathrm{H}_{\mathrm{a}}$ was accepted. Based on the computation, it can be concluded that there was correlation between students' vocabulary mastery and their translation ability at the first semester of eleventh grade of MAN 2 Bandar Lampung in the academic year of 2017/2018.

\section{B. Discussion}

The findings of the research showed that there was significant correlation between students' vocabulary mastery and their translation ability. The result was gotten from collecting and analyzing the data taking from test by using Pearson's Product moment formula. In this research, there are two types of test namely; vocabulary test and translation test. They were used to know the correlation of them. 
At the beginning of activity, the try out was conducted in MAN 2 Bandar Lampung on October $10^{\text {th }}, 2017$. Try out test given to 40 students of the eleventh grade of MAN 2 Bandar Lampung out of the sample. It was prepared in form multiple choice questions of vocabulary mastery test in 40 items, and 1the text in form essay of translating text, it held on October, $10^{\text {th }} 2017$ for Vocabulary test and on October, $15^{\text {th }} 2017$ for translation test. It hadpurposed to know how accurate and effective the test before they used to collect the data of the research and identify whether the test can be given or not. Then, the test items were evaluated to get a good items that were tested in the test. It can be seen from the result of validity and reliability of tests. After knowing the result of validity and reliability test from try out, it can be seen that the result of try out test showed that the instrument is valid and reliable.

The number of the result of items validity for vocabulary mastery test that was valid 20 items from 40 item number. The result of validity test for translating test showed both of items were valid. So, in this research, the theme of translationtest was the dog. Based on the result obtained in the Anates that reliability test in vocabulary mastery was 0.85 and fortranslation ability the researcher used inter-rater reliability was 0.941 . It can be concluded that reliability of vocabulary mastery was very high and reliability of translation ability was high and both of them were reliable. Thus, it can be used for test.

At the end of the research, vocabulary mastery and translation ability test were given to know the correlation among the variables. It was conducted in MAN 2 Bandar Lampung on Bandar Lampung onOctober $31^{\text {th }}, 2017$ and on November $4^{\text {th }}$, 2017. The test was given to 39 students from 197 populations. The sample of the research was taken from XI MIA 2 class. In collecting the data, it was used objective test that were multiple choices consisted of 20 items test, and translation test that consisted of one text the theme is the dog. In this case, the students translate a report text during 90 minutes for time allocation and 90 minutes for time allocation of vocabulary test. 
To analyze the data, SPSS (Statistical Package for the Social Science) version 16 was used to getting the result of vocabulary mastery, result of translation ability, result of normality test, and result of linearity test. In this case, Pearson product moments formulas' by using SPSS (Statistical Package for the Social Science) version 16 was used to getting the result of hypothetical test.

Based on the results obtained by using SPSS (Statistical Package for the Social Science) version 16 , the result of vocabulary mastery test was conducted in order to see students' vocabulary mastery. The minimum score was 40 and the maximum score was 95 . There were 1 student who got the score 40, 1 student who got the score 90, and 18 students got score lower than 75 . The mean of the vocabulary mastery test is 68.59 . it can be seen that there were 23 students who get under average scores and 14 students get a good scores over average score 73 ( Standard Minimum of Criteria).

The test was conducted in order to know the students' translation ability. The minimum score was 46 and the maximum score was 86 . There were 5 students who got the score 46, 1 student who got the score 86, and 29 students who got the score lower than 75 . The mean of the translation ability test is 65.38 . it can be seen that there were 28 students who got score under average scores and 11 students who got the score over average score ( Standard Minimum of Criteria).

The result of the data analysis showed that value of significant generated Sig ( $\mathrm{P}$ Value $)=0.000<\alpha=0.05$. It means that there was correlation between two variables. In this research, the independent variable, vocabulary mastery $(\mathrm{X})$ was highly influenced by dependent variable, the ability of translating (Y) and dependent variable, the translation ability (Y) was also highly influenced by the variable X.

Because by seeing the result of the data calculation in previous chapter where alternative hypothesis $\left(\mathrm{H}_{\mathrm{a}}\right)$ was consequently accepted, it means that there wascorrelation between vocabulary and translation ability at the first semester of eleventh grade of MAN 2 Bandar Lampung in 2017/2018 academic year. In other words, the null hypothesis $\left(\mathrm{H}_{\mathrm{o}}\right)$ was rejected and alternative hypothesis $\left(\mathrm{H}_{\mathrm{a}}\right)$ was 
accepted. It is supported by the research Kurniati about the correlation between part of speech mastery and translation ability. The result of the research has shown that there is positive correlation between students' part of speech mastery and translation ability. Thus indicates the connection between vocabulary mastery and translation ability is significant. Based on this research, it was suggested that to have a good in translating, students should have a good mastery of vocabulary. It means that there wascorrelation between students' vocabulary mastery and their translation ability at the first semester of eleventh grade of MAN 2 Bandar Lampung in the academic year of 2017/2018.

\section{E. CONCLUSION AND SUGGESTION}

\section{Conclusion}

After conducting the research and analyzing the data the researcher draws a conclusion as follows:

There wascorrelation between students' vocabulary mastery and their translation ability at the first semester of eleventh grade of MAN 2 Bandar Lampung inthe academic year of 2017/2018 because by seeing the result of the data calculation in the previous chapter where null hypothesis $\left(H_{o}\right)$ was rejected, and alternative hypothesis $\left(H_{a}\right)$ was accepted. It means that the researcher'sassumption was revealedthat vocabulary mastery and translation ability were correlated significantly. Pearson's product moment formula by using SPSS shows the result obtained that the value of significant generated Sig. $\left(\mathrm{P}_{\text {Value }}\right)=0.000<\alpha=0.05$. It can be revealed from the hypothesis testing.

Based on this research, it was concluded that a good ability in translating text, students should have mastery of vocabulary. It means that there wascorrelation between students' vocabulary mastery and their translation ability at the first semester of eleventh grade of MAN 2 Bandar Lampung in the academic of $2017 / 2018$.

\section{B. Suggestions}

Based on the conclusion above, the researcher gave some suggestion as follows: 


\section{Suggestion for the Teacher}

In this research, the researcher found out that the correlation between students' vocabulary mastery and their translation ability can be used to develop and motivate the students to master the vocabulary and ability in translating. Due the finding, the English teacher should give more attention and motivate the students to upgrade their vocabulary. The teachers also should give the input about students' work so they would know their weakness in translating text.

\section{Suggestion for the Students}

The students should study hard and more practice in learning English in order to develop their vocabulary mastery and their ability in translating because to get good ability in translation, the students have to master of vocabulary.

\section{Suggestion for Further Researchers}

For further researchers can also investigate the correlation between students' vocabulary mastery and their reading comprehension more depth to reinforce the result of this research and find out the better result.

\section{F. REFERENCES}

Arikunto, Suharsimi. 2013. Prosedur Penelitian Pendekatan Praktik. Jakarta : Rineka Cipta.

Ary, Donal, Jacobs, L.C., Sorensen, C., Razavieh. 2006. Introduction to Research in Education. Blemton : Wadsworth, Cengage Learning.

Brown, H. Doughlas. 2007. Principles of Language Learning and Teaching, San Fransisco: Addison Wesley Longman.

Creswell, John W. 2012. Educational Research (Planning, Conducting, and Evaluating, Quantitative and Qualitative Research). New York: Person Education.

Fardushila, Wahyu. Interview. MAN 2 Bandar Lampung : 25 January 2017 at 09 : 30 .

Fraenkel, J. R.Wallen, N. E., Hyun, H. H, (7 ${ }^{\text {th }}$ Edition). 2009. How to Design and Evaluate Research in Education Eight Edition. New York: McGraw-Hill.

Frank, Marcella. 1972. Modern English : a practical reference guide. New Jersey: Prentice Hall, Inc. 
Fromkin, Victoria et.al. 2003 An Introduction to Language,( $\left.7^{\text {th }} E d\right)$. Boston : Wadsworth Engage Learning.

Gower, Roger et.al. 1995. Teaching Practice Handbook. London: Heineman. Hatch, Evelyn and Brown, Cheryl. 1995. Vocabulary, Semantics, and Language Education. Cambridge : Cambridge University Press.

Hiebert, Elfrieda H. and L, Michael Kamil. 2005. Teaching and Learning Vocabulary : Bringing Research to Practice. London: Lawrence Erlbaum Associates.

Hornby, A S . 2010. Oxford : Advance Learner's Dictionary. London : Oxford University Press.

Kurniati, Dwi. 2014. "The Correlation between Students Part of Speech Mastery and translation ability". Thesis. Tarbiyah and Teacher training Faculty:IAIN Raden Intan Lampung.

Lester, Mark. 2009. English Grammar Drills. New York : The Mc-Graw Hill Companies.

M. Lodico. G.,Spaulding, D. T., Voegtle, K. H. 2006. Methods In Educational Research From Theory to Practice. San Fransisco: Jossey-Bass.

Machali, Rochayah. 2009. Pedoman Bagi Penerjemah. Bandung: Kaifa

Mackey, Alison and M. Gass, Susa. 2005. Second Language Research:

Methodology and Design. New Jersey: Lawrence Erlbaum Associates Inc

Midred. L. Larson. 1984. Meaning-based Translation: A Guide to Cross-language Equivalence. New York: University Press of America, Inc.

Nation, I. S. P. 2001. Learning Vocabulary In Another Language. New York : Cambridge Applied Linguistic.

Newmark, Peter. 2001. Approach to Translation. New York : Pergamon Press. Norusis, Marij. 2007 SPSS 16.0 User's Guide. Chicago : Prentice Hall.

Patel, M.F. and Jain, Preveen M. 2008. English Language Teaching (Methods, Tools, and Techniques). Jaipur : Sunrise Publishers \& Distributor.

Radford, Andrew et.al. 2009. Linguistics :An introduction $\left(2^{\text {nd }} E d\right)$. New York : Cambridge University Press.

Siahaan, Sanggman. 2008. The English paragraph. Yogyakarta: Graha Ilmu.

Setiyadi, Ag. Bambang. 2006. Teaching English as a Foreign Language. Yogyakarta: Graha Ilmu. 
English Education: Jurnal Tadris Bahasa Inggris pISSN 2086-6003 | eISSN 2580-1449 Vol 14 (2), 2021, 257-279

Setiyadi. Ag. Bambang. 2006. Metode Penelitian untuk Pengajaran Bahasa Asing Pendekatan Kuantitatif dan Kualitatif. Yogyakarta: GrahaIlmu.

Sugiyono. 2008. Metode Penelitian Kualitatif, Kuantitatif Dan R\&D. Bandung : Alfa Beta. 